\title{
KIAA1549 wt Allele
}

National Cancer Institute

\section{Source}

National Cancer Institute. KIAA1549 wt Allele. NCI Thesaurus. Code C98018.

Human KIAA1549 wild-type allele is located in the vicinity of 7q34 and is approximately $150 \mathrm{~kb}$ in length. This allele, which encodes UPF0606 protein KIAA1549, may involved in the modulation of the activity of the amygdala, the hypothalamus and other brain regions. Tandem duplication of about $2 \mathrm{Mb}$ at chromosome 7q34 that fuses this gene and the BRAF gene is associated with pilocytic astrocytoma. 